\title{
Persepsi Dokter Pendidik Klinis terhadap Perilaku Profesional Dokter Muda di Rumah Sakit Pendidikan Fakultas Kedokteran Unisba
}

\author{
Ana Nurlina, ${ }^{1}$ Miranti Kania Dewi, ${ }^{2}$ Ami Rachmi, ${ }^{3}$ Eva Rianti Indrasari, ${ }^{4}$ Mia Kusmiati ${ }^{5}$ \\ ${ }^{1}$ Program Sarjana Pendidikan Dokter, ${ }^{2}$ Departemen Farmakologi, ${ }^{3}$ Departemen Rehabilitasi Medik, \\ ${ }^{4}$ Departemen Biokimia, Fakultas Kedokteran Universitas Islam Bandung
}

\begin{abstract}
Abstrak
Masalah dalam perilaku profesional dokter semakin disorot oleh masyarakat ditandai dengan peningkatan pengaduan masyarakat ke MKDKI mengenai perilaku dokter yang dinilai kurang sesuai di antaranya mengenai komunikasi antara pasien dan dokter. Tujuan penelitian ini mengetahui persepsi dokter pendidik klinis terhadap perilaku profesional dokter muda di rumah sakit pendidikan FK Unisba. Penelitian ini menggunakan metode deskriptif dengan pendekatan cross-sectional. Pengambilan data menggunakan kuesioner kepada dokter pendidik klinis di RSUD Al-Ihsan dan RS Al-Islam Bandung. Dokter pendidik klinis menilai lima aspek perilaku profesional dokter muda, yaitu kompetensi dan keterampilan klinik sebagai dokter, kemahiran dalam berkomunikasi, sikap terhadap pasien, inisiatif dan komitmen terhadap tugas serta pekerjaan, dan sikap terhadap kolega, pembimbing klinis maupun tenaga kesehatan lainnya. Waktu pengambilan data dilakukan pada bulan Juni-Juli 2018 didapatkan 50 responden yang memenuhi kriteria inklusi, yaitu dokter pendidik klinis dari departemen yang sudah dimasuki oleh rotasi dokter muda dan dokter pendidik klinis dari departemen yang melakukan pemeriksaan langsung kepada pasien. Pengolahan data menggunakan Microsoft Excel dan disajikan dalam bentuk tabel distribusi dan frekuensi. Hasil penelitian ini menunjukkan perilaku profesional dokter muda dalam aspek kemahiran dalam berkomunikasi, penerapan perilaku profesional terhadap pasien, perilaku dokter muda terhadap kolega, dokter pembimbing klinis maupun tenaga kesehatan lainnya termasuk dalam kategori baik, sedangkan pada aspek kompetensi keterampilan klinik sebagai dokter masih dalam kategori cukup, sedangkan mengenai aspek inisiatif dan komitmen terhadap tugas serta pekerjaan memberikan hasil baik dan cukup. Hal ini dapat disebabkan oleh mahasiswa dalam menerapkan pembelajaran pada saat menjalankan kegiatan tutorial ataupun skill lab masih kurang.
\end{abstract}

Kata kunci: Dokter pendidik klinis, perilaku profesional, dokter muda

\section{Perception of Clinical Doctors Toward Professional Behavior of Young Doctors in Teaching Hospital Faculty of Medicine Unisba}

\begin{abstract}
Problems in the professional behavior of doctors are increasingly highlighted by the community marked by an increase in public complaints to MKDKI regarding the behavior of doctors who are considered inappropriate according to the communication between patients and doctors. The purpose of this study was to determine the perception of preceptor on the professional behavior of young doctors in FK Unisba teaching hospitals. This study used descriptive method with a cross-sectional approach. Data collection used a questionnaire to clinical educators at Al-Ihsan Regional Hospital and Al-Islam Hospital in Bandung. Clinical educators assess five aspects of young doctors' professional behavior, namely clinical competence and skills as doctors, communication skills, attitudes toward patients, initiative and commitment to tasks and work, and attitudes towards colleagues, clinical counselors and other health workers. When the data was collected in June-July 2018, 50 respondents who met the inclusion criteria, namely clinical educators from the department that had been entered by rotation of young doctors and clinical educators from the department who conducted direct examination of patients. Data processing in this study using Microsoft Excel and presented in the form of distribution tables and frequencies. The results of this study show the professional behavior of young doctors in aspects of communication skill, application of professional behavior to patients, the behavior of young doctors toward colleagues, clinical supervising doctors and other health workers in the good category, while in the aspect of competency in clinical skill as a doctor is still in the sufficient category, and regarding the aspects of initiative and commitment to the task and work to provide good and sufficient results. It might caused by the lack of students in applying learning when running tutorial activities or lab skills.
\end{abstract}

Key words: Clinical doctor, professional behavior, young doctor

Korespondensi: Ana Nurlina. Program Studi Pendidikan Dokter. Alamat: Jl. Tamansari No.20, Bandung 40116, Provinsi Jawa Barat Telepon: 0224203368 Faksimile: 0224203368 Email : nurlinaana.an@gmail.com. 


\section{Pendahuluan}

Terdapat beberapa pengaduan mengenai perilaku dokter yang kurang menyenangkan kepada Majelis Kehormatan Disiplin Kedokteran Indonesia (MKDKI). Ditemukan 70\% pengaduan pasien mengenai perilaku dokter yang dinilai kurang baik itu, salah satunya komunikasi antara dokter-pasien yang kurang menunjukkan terdapat masalah perilaku profesional dokter. ${ }^{1}$

Perilaku profesional menjadi kompetensi yang wajib dikuasai oleh seorang dokter. ${ }^{2}$ Sebagai dokter yang profesional, seorang dokter harus bersikap sesuai dengan kode etik kedokteran, menjaga kerahasiaan pasien, memperlihatkan kepercayaan serta saling menghormati antara dokter dan pasien, memiliki sikap empati, dan tidak membeda-bedakan berdasar atas derajat seseorang. Menjadi seorang dokter tidak hanya menjalin hubungan dengan pasien melainkan mampu bekerja sama dengan tenaga kesehatan yang lainnya, mampu menerima tanggapan yang membangun terhadap masukan yang diberikan oleh orang lain, memberikan pelayanan kesehatan di masyarakat, dan menghormati perbedaan karakter dari seseorang, gaya hidup serta budaya baik dari pasien maupun teman sejawat. $^{3}$

Pembelajaran perilaku profesional bagi mahasiswa kedokteran merupakan yang terpenting yang perlu diterapkan dalam pendidikan kedokteran. ${ }^{4}$ Pendidikan dokter secara umum mencakup pendidikan klinis dan perilaku profesional yang mempunyai peran penting dalam proses pembelajaran yang ditujukan kepada penguasaan ilmu dan keterampilan dalam membuat diagnosis, pengambilan putusan ilmiah, dan perilaku profesional dokter. Proses pembelajaran klinis dapat dilakukan di lingkungan rumah sakit ataupun di pusat kesehatan masyarakat lainnya dengan tujuan mahasiswa kedokteran mendapatkan pelajaran dan pengalaman klinis. ${ }^{5}$

Berdasar atas buku pedoman program profesi pendidikan dokter Fakultas Kedokteran (FK) Unisba mempunyai kriteria penilaian mengenai perilaku profesional khususnya bagi dokter muda yang akan menjalankan kegiatan program profesi yang terdiri atas kejujuran dan integritas kepribadian, membangun kepercayaan dan yang bertanggung jawab dalam melaksanakan profesinya, menghormati sesama, memiliki keinginan untuk selalu mengembangkan dan mencapai kesempurnaan diri, kesadaran akan batas kemampuan diri, mampu berkomunikasi dan bekerjasama, serta memiliki sikap altruism. ${ }^{6}$

Menurut penelitian yang dilakukan oleh StenforsHayes dkk.7 perilaku profesional yang baik dapat dievaluasi melalui perspektif dokter pendidik klinis dengan mencakup penilaian terhadap pengetahuan, sikap, dan juga perilaku profesional dari dokter muda. Penelitian perilaku profesional dokter muda dari perspektif dokter pendidik klinis di lingkungan Fakultas Kedokteran Unisba belum pernah dilakukan sebelumnya sehingga penelitian ini dilakukan dengan tujuan mengetahui persepsi dokter pendidik klinis terhadap perilaku profesional dokter muda di rumah sakit Pendidikan FK Unisba.

\section{Metode}

Metode yang digunakan adalah deskriptif dengan pendekatan secara cross-sectional melalui penyebaran kuesioner yang sebelumnya sudah diuji validiatas dan realibitasnya kepada dokter pendidik klinis sehingga penelitian ini dapat dilaksanakan untuk mengetahui persepsi dokter pendidik klinis terhadap perilaku profesional dokter muda di Rumah Sakit Pendidikan Fakultas Kedokteran Unisba yang dilakukan di dua rumah sakit, yaitu RSUD Al-Ihsan Bandung dan RS Al-Islam Bandung. Waktu penelitian dilakukan pada bulan Juni-Juli dan didapatkan 50 responden yang telah memenuhi kriteria inklusi, yaitu dokter pendidik klinis dari departemen yang dimasuki oleh rotasi dokter muda dan dokter pendidik klinis dari departemen yang melakukan pemeriksaan langsung kepada pasien sehingga dapat mengetahui persepsi dokter pendidik klinis mengenai aspek kompetensi klinis sebagai dokter, kemahiran dalam berkomunikasi, perilaku profesional terhadap pasien, inisiatif dan komitmen terhadap tugas dan pekerjaan, serta perilaku terhadap kolega, pembimbing dan tenaga kesehatan lain.

Skoring penentuan perilaku ini dikategorikan menjadi tiga kategori, yaitu: ${ }^{8,9}$ 1) kategori keterampilan klinis sebagai dokter: baik $\geq 17,3$; cukup 12,517,2; kurang $\leq 12,6$; 2) kategori kemahiran dalam berkomunikasi: baik $\geq 10,3$; cukup 7,7-10,2; kurang $\leq 7,6$; 3) kategori perilaku terhadap pasien: baik $\geq 23,3$; cukup $18,7-23,3$; kurang $\leq 18,6$; 4) kategori komitmen dan inisiatif dokter muda terhadap tugas dan pekerjaan: baik $\geq 17,1$; cukup 12,9-17,1; kurang $\leq 12,8$; 5) kategori perilaku terhadap kolega, dokter pendidik klinis, dan tenaga kesehatan lain: baik $\geq 10$; cukup 9-10; kurang $\leq 8$. Penelitian ini sudah mendapat persetujuan etik oleh Komite Etik Penelitian Kesehatan Fakultas Kedokteran Islam Bandung dengan Nomor: 310/Komite Etik.FK/III/2018.

\section{Hasil}

Berdasar atas penyebaran kuesioner kepada 50 dokter pendidik klinis di dua Rumah Sakit Pendidikan FK Unisba, yaitu RSUD Al-Ihsan dan RS Al-Islam Bandung didapatkan hasil seperti yang terlihat pada Tabel di bawah ini.

\begin{tabular}{|c|c|c|c|}
\hline \multirow[t]{2}{*}{ Tabel 1} & \multirow{2}{*}{$\begin{array}{l}\text { Karakteristik } \\
\text { atas Umur, } \\
\text { Departemen }\end{array}$} & Responden & Berdasar \\
\hline & & Jenis & Kelamin, dar \\
\hline \multicolumn{2}{|c|}{ Karakteristik } & $\mathrm{n}=50$ & Persentase (\%) \\
\hline \multicolumn{4}{|c|}{ Usia (tahun) } \\
\hline \multicolumn{2}{|c|}{$>35$} & 1 & 2 \\
\hline \multicolumn{2}{|c|}{$35-40$} & 6 & 12 \\
\hline \multicolumn{2}{|c|}{$>40$} & 43 & 86 \\
\hline \multicolumn{4}{|c|}{ Jenis kelamin } \\
\hline \multicolumn{2}{|c|}{$\begin{array}{l}\text { Laki-laki } \\
\text { Peremnun }\end{array}$} & 28 & 56 \\
\hline Peren & puan & 22 & 44 \\
\hline \multicolumn{4}{|c|}{ Bagian } \\
\hline \multicolumn{2}{|c|}{ Bagian dasar* } & 33 & 66 \\
\hline \multicolumn{2}{|c|}{ Bagian non-dasar ${ }^{* * *}$} & 17 & 34 \\
\hline
\end{tabular}

\footnotetext{
* penyakit dalam, obgin, bedah, dan anak

** saraf, anastesi, mata, THT, gigi, psikiatrik, rehabilitasi medik, radiologi
} 
Karakteristik usia dokter pendidik klinis mayoritas berusia $>40$ tahun (86\%), laki-laki 28 orang (56\%), dan dari bagian dasar 33 orang (66\%), (Tabel 1).

Sebagian besar dokter pendidik klinis menilai perilaku dokter muda mengenai aspek kompetensi dan keterampilan klinis sebagai dokter memiliki kategori cukup, sedangkan sebagian kecil dokter pendidik klinis memberikan penilaian yang baik dan memberikan penilaian yang kurang (Tabel 2).

Tabel 2 Distribusi Frekuensi Kompetensi Dokter Muda di Rumah Sakit Pendidikan Fakultas Kedokteran Unisba

\begin{tabular}{lcc}
\hline \multicolumn{1}{c}{ Skor } & n=50 & Persentase (\%) \\
\hline Baik & 13 & 26 \\
Cukup & 23 & 46 \\
Kurang & 14 & 28 \\
\hline
\end{tabular}

Item pernyataan tentang kompetensi keterampilan klinis sebagai dokter seluruh responden menjawab cukup/netral. Item pernyataan nomor 1 sejumlah $36 \%$, item pernyataan nomor 2 sejumlah $44 \%$, item pernyataan nomor 3 sejumlah $54 \%$, item pernyataan nomor 4 sejumlah $38 \%$, dan untuk pernyataan nomor 5 sejumlah 38\%. Jika dimasukkan dalam 3 kategori keseluruhan kompetensi dokter muda sebagai dokter masuk dalam kategori cukup (Tabel 3).

Sebagian besar dokter pendidik klinis menilai perilaku dokter muda mengenai aspek kemahiran dalam berkomunikasi memiliki kategori baik, sebagian kecil dokter pendidik klinis memberikan penilaian yang kurang, sedangkan dokter pendidik klinis yang memberikan penilaian kurang sekitar 8\% (Tabel 4).

Setiap dari item pernyataan memberikan hasil yang bervariasi pada item seperti pernyataan nomor 6 sebagian responden memberikan jawaban setuju $58 \%$, sedangkan item pernyataan nomor 7 sebagian

Tabel 3 Analisis Deskriptif Variabel Kompetensi Sebagai Dokter

\begin{tabular}{|c|c|c|c|c|c|c|c|c|c|c|c|}
\hline \multirow{3}{*}{ No } & \multirow{3}{*}{ Item Pertanyaan } & \multicolumn{10}{|c|}{ Skor } \\
\hline & & \multicolumn{2}{|c|}{ SS } & \multicolumn{2}{|c|}{$\mathbf{S}$} & \multicolumn{2}{|c|}{$\mathbf{N}$} & \multicolumn{2}{|c|}{ TS } & \multicolumn{2}{|c|}{ STS } \\
\hline & & $\mathbf{n}$ & $\%$ & $\mathbf{n}$ & $\%$ & n & $\%$ & $\mathbf{n}$ & $\%$ & $\mathbf{n}$ & $\%$ \\
\hline 1 & $\begin{array}{l}\text { Dokter muda sangat terampil dalam melakukan } \\
\text { anamnesis terhadap pasien. }\end{array}$ & 2 & 4 & 16 & 32 & 18 & 36 & 14 & 28 & 0 & o \\
\hline 2 & $\begin{array}{l}\text { Dokter muda sangat terlatih melakukan } \\
\text { pengelolaan pasien. }\end{array}$ & 2 & 4 & 5 & 10 & 22 & 44 & 21 & 42 & 0 & o \\
\hline 3 & $\begin{array}{l}\text { Dokter muda terampil menegakkan diagnosis } \\
\text { dan merencanakan penatalaksanaannya. }\end{array}$ & $\mathrm{O}$ & $\mathrm{O}$ & 10 & 20 & 27 & 54 & 13 & 26 & $\mathrm{O}$ & $\mathrm{O}$ \\
\hline 4 & $\begin{array}{l}\text { Dokter muda melakukan penanganan terhadap } \\
\text { pasien secara terarah dan holistik. }\end{array}$ & 1 & 2 & 14 & 28 & 19 & 38 & 16 & 32 & O & o \\
\hline 5 & $\begin{array}{l}\text { Dokter muda mampu melakukan tindakan- } \\
\text { tindakan yang menjadi kompetensinya }\end{array}$ & 5 & 10 & 14 & 28 & 19 & 38 & 11 & 22 & 1 & 2 \\
\hline
\end{tabular}

Keterangan: $\mathrm{SS}=$ sangat setuju, $\mathrm{S}=$ setuju, $\mathrm{N}=$ netral, TS=tidak setuju, $\mathrm{STS}=$ =sangat tidak setuju

Tabel 4 Distribusi Frekuensi Kemahiran Berkomunikasi Dokter Muda di Rumah Sakit Pendidikan Fakultas Kedokteran Unisba

\begin{tabular}{cccc}
\hline Skor & $\mathbf{n = 5 0}$ & Persentase (\%) \\
\hline Baik & 24 & 48 \\
Cukup & 22 & 44 \\
Kurang & 4 & 8 \\
\hline
\end{tabular}

Tabel 5 Analisis Deskriptif Variabel Kemahiran dalam Berkomunikasi

\begin{tabular}{|c|c|c|c|c|c|c|c|c|c|c|c|}
\hline \multirow{3}{*}{ No } & \multirow{3}{*}{ Item Pertanyaan } & \multicolumn{10}{|c|}{ Skor } \\
\hline & & \multicolumn{2}{|c|}{ SS } & \multicolumn{2}{|c|}{$\mathbf{S}$} & \multicolumn{2}{|c|}{$\mathbf{N}$} & \multicolumn{2}{|c|}{ TS } & \multicolumn{2}{|c|}{ STS } \\
\hline & & $\mathbf{n}$ & $\%$ & $\mathbf{n}$ & $\%$ & $\mathbf{n}$ & $\%$ & $\mathbf{n}$ & $\%$ & $\mathbf{n}$ & $\%$ \\
\hline 6 & $\begin{array}{l}\text { Dokter muda mampu berkomunikasi dengan baik terhadap } \\
\text { pasien dan keluarganya. }\end{array}$ & 4 & 8 & 29 & 58 & 13 & 26 & 4 & 8 & 0 & $\mathrm{O}$ \\
\hline 7 & $\begin{array}{l}\text { Dokter muda menguasai ilmunya saat mempresentasikan } \\
\text { sebuah kasus. }\end{array}$ & 2 & 4 & 21 & 42 & 21 & 42 & 5 & 10 & 1 & 2 \\
\hline 8 & $\begin{array}{l}\text { Dokter muda dapat memberikan konseling, informasi, dan } \\
\text { edukasi kepada pasien cukup jelas, serta tidak bertele-tele. }\end{array}$ & 4 & 8 & 20 & 40 & 21 & 42 & 5 & 10 & $\mathrm{O}$ & $\mathrm{O}$ \\
\hline
\end{tabular}


Tabel 6 Distribusi Frekuensi Perilaku Dokter Muda terhadap Pasien di Rumah Sakit Pendidikan Fakultas Kedokteran Unisba

\begin{tabular}{ccc}
\hline Skor & Frekuensi & Persentase (\%) \\
\hline Baik & 38 & 76 \\
Cukup & 12 & 24 \\
Kurang & 0 & 0 \\
\hline
\end{tabular}

Tabel $7 \quad$ Analisis deskriptif Variabel Perilaku Profesional terhadap Pasien

\begin{tabular}{|c|c|c|c|c|c|c|c|c|c|c|c|}
\hline \multirow{3}{*}{ No } & \multirow{3}{*}{ Item Pertanyaan } & \multicolumn{10}{|c|}{ Skor } \\
\hline & & \multicolumn{2}{|c|}{ SS } & \multicolumn{2}{|c|}{$\mathbf{S}$} & \multicolumn{2}{|c|}{$\mathbf{N}$} & \multicolumn{2}{|c|}{ TS } & \multicolumn{2}{|c|}{ STS } \\
\hline & & $\mathbf{n}$ & $\%$ & $\mathbf{n}$ & $\%$ & $\mathbf{n}$ & $\%$ & $\mathbf{n}$ & $\%$ & $\mathbf{n}$ & $\%$ \\
\hline 9 & $\begin{array}{l}\text { Dokter muda menunjukkan sikap empati terhadap } \\
\text { pasien dan keluarganya. }\end{array}$ & 7 & 14 & 29 & 58 & 13 & 26 & 1 & 2 & O & o \\
\hline 10 & $\begin{array}{l}\text { Dokter muda menunjukkan sikap sopan terhadap } \\
\text { pasien dan keluarganya. }\end{array}$ & 6 & 12 & 38 & 76 & 6 & 12 & 0 & 0,0 & O & O \\
\hline 11 & $\begin{array}{l}\text { Dokter muda berkomitmen terhadap mutu } \\
\text { pelayanan yang diberikan terhadap pasien. }\end{array}$ & 5 & 10 & 31 & 62 & 12 & 24 & 2 & 4 & O & o \\
\hline 12 & $\begin{array}{l}\text { Dokter muda sangat memegang teguh prinsip- } \\
\text { prinsip keselamatan pasien. }\end{array}$ & 6 & 12 & 28 & 56 & 12 & 24 & 4 & 8 & O & O \\
\hline 13 & $\begin{array}{l}\text { Dokter muda sangat antusias dan telaten dalam } \\
\text { melayani pasien. }\end{array}$ & 4 & 8 & 21 & 24 & 20 & 40 & 5 & 10 & $\mathrm{O}$ & O \\
\hline 14 & $\begin{array}{l}\text { Dokter muda menunjukkan sikap sabar ketika } \\
\text { melayani pasien. }\end{array}$ & 4 & 8 & 26 & 52 & 19 & 38 & 1 & 2 & O & o \\
\hline 15 & $\begin{array}{l}\text { Dokter muda mengetahui dengan baik apa yang } \\
\text { menjadi masalah pasiennya. }\end{array}$ & 22 & 44 & 18 & 36 & 10 & 20 & 0 & 0,0 & O & O \\
\hline
\end{tabular}

Keterangan: SS=sangat setuju, S=setuju, N=netral, TS=tidak setuju, STS=sangat tidak setuju

Tabel 8 Distribusi Frekuensi Inisiatif dan Komitmen Dokter Muda Terhadap Tugas dan Pekerjaan di Rumah Sakit Pendidikan Fakultas Kedokteran Unisba

\begin{tabular}{ccc}
\hline Skor & n=50 & Persentase (\%) \\
\hline Baik & 24 & 48 \\
Cukup & 24 & 48 \\
Kurang & 2 & 4 \\
\hline
\end{tabular}

Tabel 9 Analisis deskriptif Variabel Inisiatif dan Komitmen terhadap Tugas dan Pekerjaan

Keterangan: $\mathrm{SS}=$ sangat setuju, $\mathrm{S}=$ setuju, $\mathrm{N}=$ netral, $\mathrm{TS}=$ tidak setuju, $\mathrm{STS}=$ sangat tidak setuju 
Tabel 10 Distribusi Frekuensi Perilaku Dokter Muda terhadap Kolega, Pembimbing, dan Tenaga Kesehatan Lain di Rumah Sakit Pendidikan Fakultas Kedokteran Unisba

\begin{tabular}{ccc}
\hline Skor & n=50 & Persentase (\%) \\
\hline Baik & 41 & 82 \\
Cukup & 9 & 18 \\
Kurang & 0 & 0 \\
\hline
\end{tabular}

Tabel 11 Analisis deskriptif Variabel Perilaku terhadap Kolega, Pembimbing, dan Tenaga Kesehatan Lain

\begin{tabular}{|c|c|c|c|c|c|c|c|c|c|c|c|}
\hline \multirow{3}{*}{ No } & \multirow{3}{*}{ Item Pertanyaan } & \multicolumn{10}{|c|}{ Skor } \\
\hline & & \multicolumn{2}{|c|}{ SS } & \multicolumn{2}{|c|}{$\mathbf{S}$} & \multicolumn{2}{|c|}{$\mathbf{N}$} & \multicolumn{2}{|c|}{$\mathbf{T S}$} & \multicolumn{2}{|c|}{ STS } \\
\hline & & $\mathbf{n}$ & $\%$ & $\mathbf{n}$ & $\%$ & $\mathbf{n}$ & $\%$ & $\mathbf{n}$ & $\%$ & $\mathbf{n}$ & $\%$ \\
\hline 21 & $\begin{array}{l}\text { Dokter muda menunjukkan perilaku yang baik } \\
\text { terhadap tenaga kesehatan lain. }\end{array}$ & 5 & 10 & 34 & 68 & 11 & 22 & O & O & O & O \\
\hline 22 & $\begin{array}{l}\text { Mereka menghargai teman sejawat dan tenaga } \\
\text { kesehatan lain di rumah sakit. }\end{array}$ & 5 & 10 & 38 & 76 & 7 & 14 & o & 0 & 0 & o \\
\hline 23 & $\begin{array}{l}\text { Dokter muda selalu menghormati dokter } \\
\text { pembimbingnya maupun dokter yang berjaga } \\
\text { di rumah sakit. }\end{array}$ & 7 & 14 & 34 & 68 & 9 & 18 & 0 & $\mathrm{O}$ & $\mathrm{O}$ & o \\
\hline
\end{tabular}

responden memberikan hasil yang seimbang cukup maupun setuju mengenai kemahiran berkomunikasi dokter muda (42\%) dan untuk item pernyataan nomor 8 sebagian responden memberikan hasil cukup (42\%). Namun, hasil keseluruhan perilaku dokter muda mengenai kemahiran berkomunikasi masuk dalam kategori baik (Tabel 5).

Mayoritas dokter pendidik klinis menilai perilaku dokter muda mengenai aspek perilaku terhadap pasien memiliki kategori baik, sebagian kecil memberikan penilaian yang cukup, dan tidak ada penilaian kurang (Tabel 6).

Pernyataan nomor 9 hingga nomor 14 sebagian responden memberikan jawaban setuju. Item pernyataan nomor 9 sebesar $58 \%$, item pernyataan nomor 10 sebesar $76 \%$, item pernyataan nomor 11 sebesar $62 \%$, item pernyataan nomor 12 sebesar $56 \%$, item pernyataan nomor 13 sebesar 42\%, dan item pernyataan nomor 14 sebesar $52 \%$, sedangkan untuk item pernyataan pada nomor 15 sebagian responden menjawab sangat setuju 44\% sehingga jika dimasukkan dalam 3 kategori keseluruhan perilaku dokter muda terhadap pasien masuk dalam kategori baik (Tabel 7).

Sebagian besar dokter pendidik klinis menilai perilaku dokter muda mengenai aspek terhadap tugas dan pekerjaannya memberikan hasil baik dan cukup, sedangkan dokter pendidik klinis yang memberikan penilaian kurang sekitar 4\% (Tabel 8).

Item pernyataan nomor $16,17,19$, dan 20 sebagian responden menjawab setuju. Untuk item pernyataan nomor 16 sebesar 50\%, item pernyataan nomor 17 sebesar $48 \%$, item pernyataan nomor 19 sebesar $46 \%$, dan untuk item pernyataan nomor 20 sebesar $48 \%$. Namun, untuk pernyataan nomor 18 memiliki jawaban yang berbeda, yaitu cukup 48\%. Jika dimasukkan dalam 3 kategori, keseluruhan perilaku dokter muda terhadap inisiatif dan komitmen terhadap tugas dan pekerjaan masuk dalam kategori cukup maupun baik (Tabel 8).
Mayoritas dokter pendidik klinis menilai perilaku dokter muda mengenai aspek perilaku terhadap kolega, pembimbing, dan tenaga kesehatan lain memiliki kategori baik, serta sebagian kecil memberikan penilaian yang cukup, dan tidak ada yang memberikan penilaian kurang (Tabel 10).

Seluruh item pernyataan nomor 21 hingga 23 mayoritas responden menjawab setuju. Untuk item pernyataan nomor 21 sebesar $68 \%$ item pernyataan nomor 22 sebesar $76 \%$, dan item pernyataan nomor 23 sebesar $68 \%$ sehingga jika dimasukkan dalam 3 kategori keseluruhan perilaku dokter muda terhadap kolega, pembimbing, dan tenaga kesehatan lain masuk dalam kategori baik (Tabel 9).

\section{Pembahasan}

Usia dokter pendidik klinis yang berada di dua Rumah Sakit Pendidikan FK Unisba mayoritas berusia $>40$ tahun, terdiri atas 8 dokter anak, 4 dokter obgin, 4 dokter bedah, dan 7 dokter penyakit dalam dengan usia $>40$ tahun sedangkan pada Bagian non-dasar terdiri atas 11 dokter pendidik klinis dengan usia $>40$ tahun. Di RSUD Al-Ihsan terdapat 13 dokter pendidik klinis perempuan dan 19 dokter laki-laki, sedangkan di RS Al-Islam terdiri atas 9 dokter pendidik klinis perempuan dan 9 dokter laki-laki. Berdasar atas bagian dokter pendidik klinis di rumah sakit pendidikan FK Unisba terdiri atas penyakit dalam, obgin, bedah dan anak, sedangkan bagian non-dasar terdiri atas saraf, mata, THT, gigi, psikiatrik, rehabilitasi medik, dan radiologi.

Aspek kompetensi dan keterampilan klinis sebagai dokter mirip dengan hasil penelitian Kusumawati ${ }^{10}$ bahwa perilaku dokter muda yang masih dinilai kurang, yaitu mengenai kompetensi klinis dan skill. Hasil penelitian ini tidak sesuai dengan tujuan Program Pendidikan Profesi FK Unisba yang menyatakan bahwa dokter muda diharapkan mampu menyelesaikan masalah kesehatan dengan mengunakan pengetahuan 
yang dimiliki, keterampilan klinis, maupun dalam melakukan tindakan medis. ${ }^{6}$ Hasil tersebut dapat terjadi karena jumlah mahasiswa kedokteran yang terlalu banyak sehingga proses pembelajaran skill lab tidak berjalan dengan optimal atau mahasiswa kurang menerapkan pembelajaran pada saat tutorial maupun skill lab pada tahap Program Pendidikan Sarjana Kedokteran sehingga ketika mahasiswa dihadapkan padalingkungan klinik mereka masih belum menguasai kompetensi klinis sebagai dokter. Oleh karena itu, perlu evaluasi mengenai proses pembelajaran tutorial maupun skill lab dalam Program Pendidikan Sarjana Kedokteran sehingga mahasiswa lebih siap dalam menjalani kepaniteraan di rumah sakit.

Kemahiran berkomunikasi sejalan dengan hasil penelitian oleh Kusumawati ${ }^{10}$ bahwa sebagian dokter muda di Indonesia mampu berkomunikasi dengan baik dalam hal memberikan pelayanan kesehatan. Buku Pedoman Program Pendidikan Profesi Dokter menyatakan dokter muda FK Unisba sudah dapat menjalankan tugasnya sebagai dokter, yaitu mampu berkomunikasi dengan baik terhadap pasien. ${ }^{6}$

Menurut Konsil Kedokteran Indonesia tahun 2006 manfaat komunikasi efektif antara dokter dan pasien, yaitu dapat meningkatkan kepuasan pasien dalam menerima pelayanan medis dari dokter atau institusi pelayanan medis; meningkatkan kepercayaan pasien kepada dokter yang merupakan dasar hubungan dokter-pasien yang baik; meningkatkan keberhasilan diagnosis terapi dan juga tindakan medis; serta meningkatkan kepercayaan diri dan ketegaran pada pasien fase terminal dalam menghadapi penyakitnya. ${ }^{11}$ Keadaan tersebut dikarenakan dokter muda sudah dapat membangun komunikasi yang baik dengan pasien melalui memberikan informasi yang jelas mengenai rencana pengobatan yang tepat dan tujuan pengobatan tersebut dilakukan untuk kepentingan pasien sehingga pasien merasa puas dengan pelayanan kesehatan yang diberikan oleh dokter; tidak menutupi informasi penting yang sebenarnya terjadi pada pasien dengan cara ini dokter dapat meningkatkan kepercayaan pasien; dan menggunakan bahasa yang mudah dimengerti oleh pasien sehingga tidak terjadi kesalahpahaman antara pasien dan dokter.

Perilaku terhadap pasien menunjukkan bahwa dokter muda telah menjalankan profesinya dengan baik sebagai dokter sebagaimana yang tercantum dalam Kode Etik Kedokteran mengenai pasal 7a "seorang dokter harus dalam setiap praktik medisnya memberikan pelayanan yang kompeten dengan kebebasan teknis dan moral sepenuhnya, disertai rasa kasih sayang (compassion) dan penghormatan atas martabat manusia". ${ }^{12}$ Sikap dokter dalam memberikan pelayanan kesehatan terhadap pasien harus didasari dengan menunjukkan rasa empati, sikap sopan, dan sabar. Berdasar atas pasal $7 \mathrm{~d}$ "seorang dokter harus senantiasa mengingat akan kewajiban melindungi hidup mahluk insani", ${ }^{12}$ penjelasan pasal ini terkait dengan jenis pernyataan mengenai seorang dokter harus memegang prinsip-prinsip keselamatan pasien; sebagai seorang dokter harus menjunjung tinggi nilainilai keselamatan pasien; mencegah terjadi cedera yang disebabkan oleh kesalahan dalam melaksanakan suatu tindakan.
Dokter muda telah menjalankan profesinya sebagai dokter sebagaimana terdapat pada salah satu konten the five stars doctor, yaitu pada aspek decision maker yang termasuk pada pernyataan bahwa dokter muda mengetahui dengan baik apa yang menjadi masalah pasiennya, yaitu ketika dalam menjalankan praktik klinik dokter muda dapat mengemukakan pendapatnya mengenai keadaan yang dialami pasien, dan pengobatan yang tepat bagi pasien. ${ }^{13}$

Aspek inisiatif dan komitmen terhadap tugas dan pekerjaan memberikan hasil yang berbeda dengan hasil penelitian Kusumawati bahwa dokter muda itu masih kurang dalam menjalankan tanggung jawab terhadap tugas-tugasnya, sedangkan dokter muda lulusan FK Unisba telah menunjukkan sikap yang cukup baik dalam manajemen waktu, kesungguhan, dan antusias dalam menjalankan praktik kedokteran di rumah sakit pendidikan. Keadaan tersebut menunjukkan bahwa dokter muda mampu menjalankan tugasnya dengan baik pada saat menjalankan praktik klinis di lingkungan rumah sakit. Oleh karena itu, aspek tersebut perlu dipertahankan pada dokter muda dalam menjalankan praktik klinis di lingkungan rumah sakit.

Hasil penelitian mirip dengan hasil penelitian yang dilakukan Kusumawati ${ }^{10}$ mengenai dokter muda telah menjalankan profesinya sebagai seorang dokter yang telah menunjukkan perilaku yang baik terhadap teman sejawat, pembimbing, maupun kepada tenaga kesehatan lainnya. Hasil penelitian ini menunjukkan bahwa perilaku dokter muda di rumah Sakit Pendidikan Fakultas Kedokteran Unisba sudah sesuai dengan pedoman pelaksanaan kode etik kedokteran Indonesia yang tertuang dalam pasal 14 mengenai kewajiban dokter terhadap teman sejawat bahwa setiap dokter dapat memperlakukan teman sejawatnya sebagaimana ia sendiri ingin diperlakukan. ${ }^{12}$

\section{Simpulan}

Persepsi dokter pendidik klinis terhadap perilaku profesional dokter muda di Rumah Sakit Pendidikan Fakultas Kedokteran (FK) Unisba sudah termasuk dalam kategori baik pada aspek kemahiran dalam berkomunikasi, perilaku profesional terhadap pasien, perilaku dokter muda terhadap kolega, pembimbing, maupun tenaga kesehatan lainnya, sedangkan aspek mengenai kompetensi keterampilan klinik sebagai dokter masih dalam kategori cukup, dan mengenai aspek inisiatif dan komitmen dokter muda terhadap tugas dan pekerjaannya memberikan hasil baik dan cukup. Perilaku profesional dokter muda di rumah sakit pendidikan FK unisba dalam aspek kompetensi keterampilan klinik maupun inisiatif terhadap tugas dan pekerjaannya perlu ditingkatkan.

\section{Ucapan Terima kasih}

Penulis mengucapkan terima kasih yang sebesarbesarnya kepada Pimpinan RSUD AL-Ihsan Bandung dan RS Islam Bandung yang sudah memberikan izin penelitian ini. 


\section{Daftar Pustaka}

1. Pangestu Sandjaya D, Afandi D, Chandra F. Perilaku profesional tenaga kesehatan daerah pesisir pada pelayanan kesehatan primer Puskesmas Sungai Sembilan Kota Dumai Tahun 2014. JOMFDOK. 2014;1(2):1-11.

2. Purnamasari CB, Claramita M, Prabandari YS. Pembelajaran profesionalisme kedokteran dalam persepsi instruktur dan mahasiswa. JPKI. 2017;4(1):21-7.

3. Fitri AD. Penerapan multi-source feedback (MSF) dalam penilaian perilaku profesional mahasiswa kedokteran. Jambi Med J. 2015;3(1):35-44.

4. Susani YP. Metode penilaian untuk perilaku profesional: the professionalism mini-evaluation exercise (P-MEX) sebuah alternatif?. JPKI. 2013;2(1):1-8.

5. Rahmawatie DA, Rahayu GR, Prihatiningsih TS. Persepsi mahasiswa terhadap kualitas supervisi klinik di 12 rumah sakit jejaring FK Unissula. Sains Med. 2011;3(2):135-49.

6. Universitas Islam Bandung Fakultas Kedokteran. Buku pedoman program studi profesi dokter (PSPD). Bandung: FK Unisba: 2014.

7. Stenfors-Hayes T, Hult H, Dahlgren LO. What does it mean to be a good teacher and clinical supervisor in medical education?. Adv Health Sci Educ. 2011;16(2):197-210.

8. Sulistiani D. Gambaran perilaku personal hygiene dan kejadian hepatitis A pada siswa di Pesantren Daarul Muttaqien Cadas Tangerang. (diunduh 13 Mei 2018) Tersedia dari: http://repository.uinjkt. ac.id/dspace/handle/123456789/28926

9. Azwar S. Reliabilitas dan validitas. Edisi ke-4. Yogyakarta: Pustaka Belajar; 2012.

10. Kusumawati W. Profesionalisme dan professional behavior mahasiswa Program Studi Pendidikan Dokter Fakultas Kedokteran dan Ilmu Kesehatan Universitas Muhammadiyah Yogyakarta Study Programme Medical Education Faculty of Medicine and Health Science. J Mutiara Med. 2016;11(1):37-45.

11. Konsil Kedokteran Indonesia. Komunikasi efektif dokter-pasien. Jakarta: KKI; 2006.

12. Ikatan Dokter Indonesia. Kode etik kedokteran Indonesia dan pedoman pelaksanaan kode etik kedokteran Indonesia. Jakarta: Majelis Kehormatan Etik Kedokteran Indonesia, Ikatan Dokter Indonesia; 2002.

13. Boelen C. The five-star doctor: an asset to health care reform?. (diunduh 14 Mei 2018) Tersedia dari: http://www.who.int/hrh/en/HRDJ_1_1_02.pdf. 